\title{
Theology, economy and environment
}

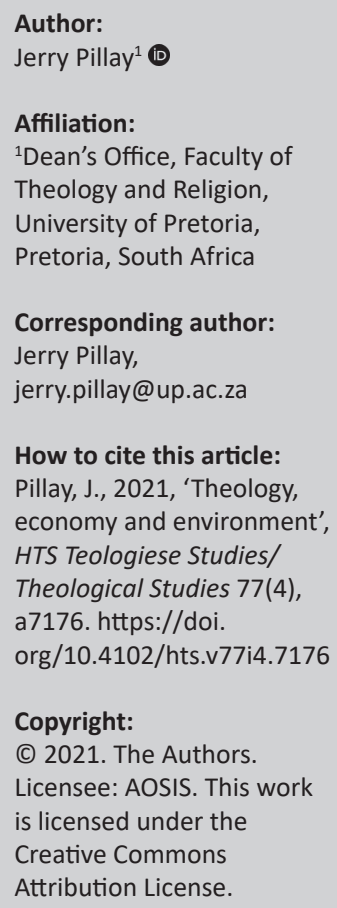

The Faculty of Theology and Religion has four focused research themes: Religion and sustainable development, Inclusive cities and communities, Economics, ecology and theology, and Faith and science. Each year we attempt to encourage academic staff and research associates to contribute to an edition covering one of the research themes of the Faculty. This particular edition addresses the theme on Economics, Ecology and Theology.

We live in a world today, in which the rich become richer and the poor become poorer. Economic injustices are prevalent in virtually every country and context and economic systems seem to benefit the wealthy and powerful. Linked to economics is ecology because the earth is the material basis for existence. The way we care for and sustain the earth is imperative as we consider future generations and the need for survival, especially in the context of climate change and environmental degradation. If we consider that the world belongs to the Lord and everything in it (Ps 24), then theology must partner in conversation with economics and ecology. The World Council of Churches has helped us to view the connection in its understanding of the integrity of God's creation.

The World Council of Churches Theological Consultation on Economy of Life pointed out the Economy of Life as an expression of koinonia (community):

$[W]$ here healthy communities flourish in peace and harmony with one another and with God's creation (Acts 2:42-47). It is a place where all people have a dignified, clean and safe place to live and die among family and friends who love and share life with them; where work has dignity and wages are fair and just; where justice is done, mercy is loved, and all walk humbly with God (Micah 6:8); and where the Earth's beings - microbes, plants, and humpback whales; seas, lakes, rivers and skies; the depths of the Earth and the hidden waters - live in the integrity God has made. (WCC Consultation, Chennai, India, 27-30 October 2014)

The above statement establishes that at the heart of theology is the understanding of God's presence and movement in the world. Theology has the task of critically analysing, reflecting and prophetically speaking to issues in the world. It has the responsibility of taking up the cause of the poor, marginalised and disadvantaged to mirror the image of a just and loving God who favours the poor and oppressed. Theology that matters must be able to interpret the sacred texts in the context of life experiences. Theology must engage the realities of the world to ensure the abundance of life for all creation, which includes economics and ecology, the two key frameworks of the 21st-century existence.

This edition on Theology, Economy and Environment aims to continue the conversation, assert the linkages and demonstrate that a theology that matters is a theology which takes world experiences seriously, especially that of the poor and needy. The articles contributed to this volume aim to unpack and illustrate the aspects of linking economics and ecology to theology. My hope is that the contributions of the authors would continue to stir and steer the conversations as we continue to struggle with economic, ecological and gender injustices in the world.
Note: Special Collection: Theology, Economy and Environment: Social, Cultural and Biotic Influences on Religious Communities, subedited by Jerry Pillay (University of Pretoria). 